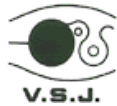

\title{
多孔質型感圧塗料の光劣化に関する研究
}

\author{
眞木 裕教 1)，藤江 康裕 2)，坂村 芳孝 3)
}

\section{An Experimental Study on the Photodegradation of Porous \\ Pressure-Sensitive Paints}

\begin{abstract}
Hirokazu MAKI, Yasuhiro FUJIE and Yoshitaka SAKAMURA

The photodegradation that occurs in pressure-sensitive paint (PSP) is one of the serious error sources for pressure measurements using PSP. The aim of the present work is to examine the photodegradation properties of porous-type PSPs with three luminescent dyes (pyrene-butyric acid (PBA), bathophenanthroline ruthenium (II) complex $\left(\mathrm{Ru}\left(\mathrm{Ph}_{2}-\mathrm{phen}\right)\right)$ and meso-tetra (pentafluorophyenyl) porphine ( $\left.\mathrm{H}_{2} \mathrm{TFPP}\right)$ ) and the effects of additives (phenolic antioxidant, sulfuric antioxidant and hindered amine light stabilizer) on the photodegradation of the PSPs. The temporary changes in the luminescent intensity of the PSPs illuminated by a Hg-Xe lamp were measured under atmospheric pressure and room temperature for $1800 \mathrm{~s}$. The results indicate that the photodegradation of PBA-PSP progresses more rapidly than those of other PSPs tested. It is also shown that the sulfuric antioxidant and the hindered amine light stabilizer are effective to reduce the photodegradation of $\mathrm{H}_{2}$ TFPP-PSP, but the phenolic antioxidant promotes the photodegradation of all PSPs tested.
\end{abstract}

Keywords : Porous pressure-sensitive paint, Photodegradation, Stabilizer

\section{1. 緒言 \\ 1.1 感圧塗料}

感圧塗料 (Pressure-sensitive paint, PSP) は, 空気中 に置かれた物体表面の圧力を光学的に計測するために開 発された機能性塗料であり, 発光色素とそれを物体表面に 固定するためのバインダーから構成される(Liu and Sullivan1) 等). Fig. 1 に示すように, PSP に特定の波長 の光（励起光）を照射すると PSP 中の色素からルミネッ センスが放射されるが，その強度は空気中の酸素分子によ る消光作用 2)のため物体表面の空気圧力に依存して変化 する.PSP は，この現象を利用して非接触・非侵襲的に 物体表面の圧力を計測しようとするもので，例えば CCD (Charge-Coupled Device)カメラなどのイメージセンサを 用いれば，表面圧力分布を可視化することができる.

上述した計測原理から明らかなように，PSP による表 面圧力計測では, 酸素消光以外の要因によるルミネッセン スの発光強度の変化は計測誤差となるため, 最小限に抑え る必要がある. 計測対象の表面温度変化はその一例で, 最

* 原稿受付 2008 年 2 月 6 日

1）富山県立大学 大学院 工学研究科

（干939-0398 富山県射水市黒河 5180）

2) 同上 (現在の所属: 株式会社タカギセイコー)

3) 正会員 富山県立大学 工学部

(E- mail: sakamura@pu-toyama.ac.jp)
大の誤差要因 3) と考えられているが, 様々な対策が講じら れている ${ }^{4 \sim 6)}$. 一方, PSP の光劣化（詳細は後述する）も 不可避な誤差要因と考えられる 7)が, 励起光の照射時間を 制限寸ること以外に効果的な防止策は見出されていない.

\section{2 光劣化}

ルミネッセンス（蛍光，リン光）の発光原理を Fig. 2 に示す 8). 励起光を照射された発光色素は, 基底一重項状 態から励起一重項状態に遷移する. 励起一重項状態から基 底状態に失活するとき放射される光は蛍光と呼ばれ, 系間 交差を経て励起三重項状態から失活するときに放射され る光はリン光と呼ばれる. PSP は, 励起三重項状態にあ る色素が周囲の酸素分子にそのエネルギーの一部を奪わ れることでルミネッセンス（主にリン光）の強度が減少す る現象を利用している。このとき基底状態の酸素分子 ${ }^{3} \mathrm{O}_{2}$ は反応性の高い励起一重項状態 ${ }^{1} \mathrm{O}_{2}$ となる.

光励起された色素の一部が光を放射することなくラジ カル種へと分解したり, 励起酸素分子と色素との反応が起 こると, ルミネッセンス強度は減少する.これは光劣化と 呼ばれる．非定常流れ場にPSP を適用する場合，高い時 間応答性が必要となるため, バインダーとして多孔質材が 利用されることがあるが 9), 多孔質型 PSP では発光色素 


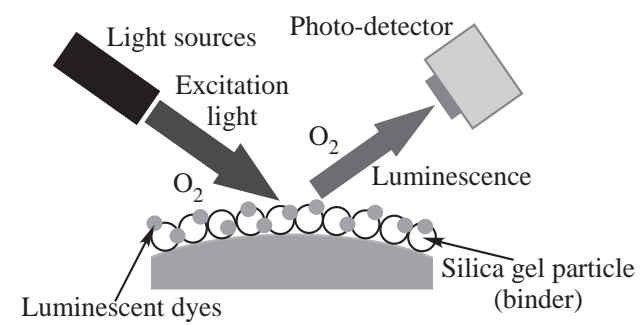

(a) Luminescence emission under low pressure conditions.

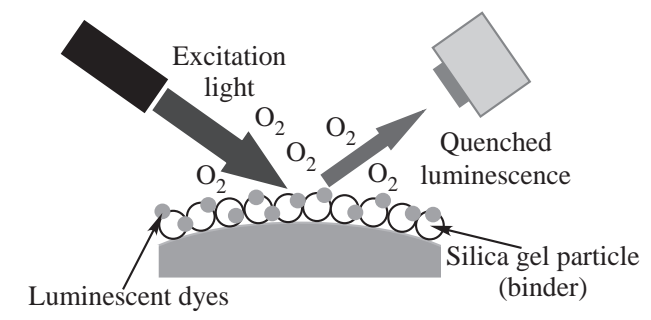

(b) Luminescence emission under high pressure conditions.

Fig. 1 Schematic of pressure measurement concept using porous PSP.

が多孔質材表面に吸着し空気に曝されているため, 酸素透 過性ポリマーをバインダーとするポリマー型 PSP と比べ て, 色素と励起酸素分子との衝突頻度が高く, 光劣化が起 こりやすい状態にあると考えられる。

一方, 有機高分子材料においても, 光に曝されているう ちに高分子鎖が切れ，材料としての特性が失われることが ある. 有機高分子材料の光劣化の抑制には, 安定化剂と呼 ばれる添加凰が用いられている ${ }^{10)}$. 江上と浅井 ${ }^{11)}$ は安定 化剂によって PSP の光劣化を抑制することを考え，PBA (Pyrene-Butyric Acid) を使用した多孔質型 PSP に対す る, いくつかの安定化剂の光劣化抑制効果を確認した. 多 孔質型 PSP の光劣化を防止するための方法として, 彼ら の方法は極めて有効なものとなることが期待されるが,

PBA 以外の色素に対しても同様の効果が得られるか否か については明らかでなく, さらなる研究が必要である。

\section{3 本研究の目的}

本研究は, 代表的な発光色素を含む多孔質型 PSP の光 劣化特性を実験的に調べ, 光劣化に起因寸る圧力計測誤差 の軽減のための方策を検討するものである. 発光色素の異 なる 3 種類のPSP に対して安定化剤を添加し, その有効 性を調べた。発光色素として, $\mathrm{Ru}\left(\mathrm{Ph}_{2}\right.$-phen) (bathophenanthroline ruthenium (II) complex), $\mathrm{H}_{2}$ TFPP (meso-tetra (pentafluorophenyl) porphine), PBA を選択した. $\mathrm{Ru}\left(\mathrm{Ph}_{2}\right.$-phen) は, 圧力感度が高く, 青色発光ダイオードで励起することができること 12)等か ら，広く利用されている。また， $\mathrm{H}_{2}$ TFPP は TLC (Thin

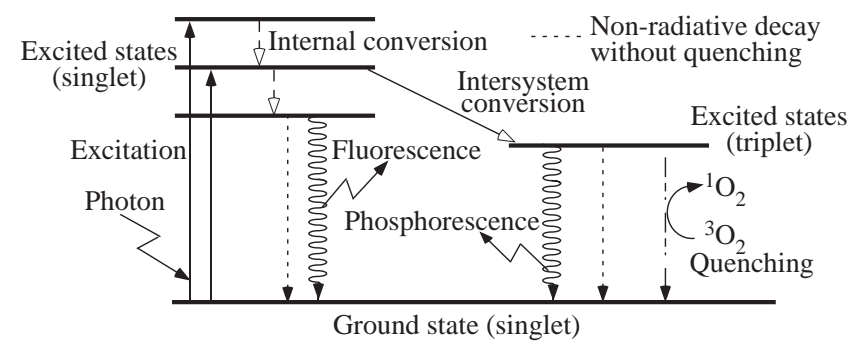

Fig. 2 Jablonski energy-level diagram.

Layer Chromatography)プレートなどの多孔質バインダ 一と組夕合わせたとき, 大気圧近傍においても高い発光強 度を示し, 非定常計測 13)で使用されている. PBA は非常 に短い発光寿命(数 ns) を有すること ${ }^{14}$ )から，高速応答型 PSP への適用が期待されている. これら 3 種の発光色素 を用いた PSP の光劣化を抑制することができれば，以上 の利点を活かした PSP 圧力計測をより高い精度で実現す ることができる。

\section{PSP による圧力計測原理}

酸素消光によるルミネッセンスの発光強度 $I$ の変化は 以下の Stern-Volmer 式で表すことができる ${ }^{15)}$.

$$
\frac{I_{0}}{I}=1+K_{\mathrm{sv}}\left[\mathrm{O}_{2}\right]
$$

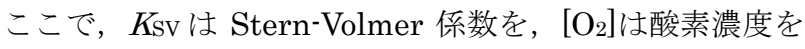
表している．また， $I_{0}$ は無酸素状態での発光強度である. 空気の組成に変化が無ければ酸素濃度は空気圧力 $p$ に比 例するので，上式は次のように書き換えられる.

$$
\frac{I_{0}}{I}=1+K p
$$

ただし $K\left(\propto K_{\mathrm{SV}}\right)$ は定数である.

$I_{0} / I$ を基準状態 $\left(p=p_{\mathrm{ref}}\right)$ における值で正規化すると

$$
\frac{I_{\mathrm{ref}}}{I}=A+B \frac{p}{p_{\mathrm{ref}}}
$$

となる.ここで，

$$
A=\frac{1}{1+K p_{\mathrm{ref}}}, B=\frac{K p_{\mathrm{ref}}}{1+K p_{\mathrm{ref}}}
$$

である. 式(3)はPSPによる圧力測定の基礎式であり，こ れを用いることでルミネッセンスの発光強度から圧力を 算出することができる.

\section{3. 光劣化のメカニズム}

有機高分子の光劣化機構 16$)$ E F g. 3 に示す. 有機高分 子の光劣化は有機化合物の光反応によって進行する. 有機 化合物である発光色素を含む PSP の光劣化もこれと類似 の機構をもつものと考えられる. なお，図中に示した RH は有機化合物(PSP の場合は発光色素)を表わしている.

光劣化は, 以下に示寸光分解と光酸化の 2 つの機構に よって進行する。 


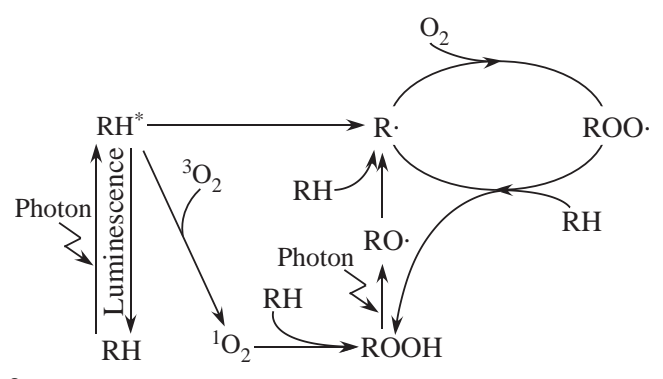

Fig. 3 Typical mechanisms of photodegradation of organics.

\section{1 光分解}

励起状態となった色素は不安定であるため, エネルギー を放出することなく, 色素自身がラジカルや原子に分解し てしまうことがある。これを光分解 (Photodecomposition）と呼ぶ.

\section{2 光酸化}

光酸化には, 酸化過程にラジカルが関わる自動酸化 (Auto-oxidation) と,ラジカルの存在に関係なく発生する 非ラジカル酸化（Non-radical oxidation）とがある.

\section{（1）自動酸化}

光分解や後述する不安定なヒドロペルオキシド $(\mathrm{ROOH})$ の分解によって生じたラジカル $(\mathrm{R} \cdot)$ は空気中 の酸素と反応する. その結果発生したラジカル $(\mathrm{ROO} ・)$ が近くの色素と反応を起こすことで元の $\mathrm{R} ・ に$ 戻り，この $\mathrm{R}$ ・が再び酸素と反応する.このようなラジカルの酸化と 還元によるループを自動酸化という。この反応は, 一度開 始するとその進行に光は必要なく, 光の照射を終えた後も 連鎖的に色素を酸化し続ける.つまり，励起光を遮断した 後も酸化反応によって色素が分解され続ける.

\section{(2) 非ラジカル酸化}

酸素消光によって励起状態の色素からエネルギーを得 た酸素は基底三重項状態 $\left({ }^{3} \mathrm{O}_{2}\right)$ から一重項状態 $\left({ }^{1} \mathrm{O}_{2}\right)$ に 励起する. この状態の酸素は反応性が高く, 色素分子と酸 化反応を起こす.このような反応は非ラジカル酸化と呼ば れており，以下の過程で色素分子を酸化する.

$$
\mathrm{RH}+{ }^{1} \mathrm{O}_{2} \rightarrow \mathrm{ROOH}
$$

非ラジカル酸化によってヒドロペルオキシドが生成する が, この物質は不安定で長波長の光によっても容易に分解 し，活性なアルコキシルラジカル $(\mathrm{RO} ・)$ を生成する.ア ルコキシルラジカルは色素と反応することで自動酸化の 原因 $(\mathrm{R} \cdot)$ となる.

\section{4. 安定化剂}

有機高分子の光劣化を防止するために用いられる安定 化剂 10) は, 分子の光励起を妨げるものや励起分子を消光 するもの, 自動酸化の進行を抑制するものなど, その効果

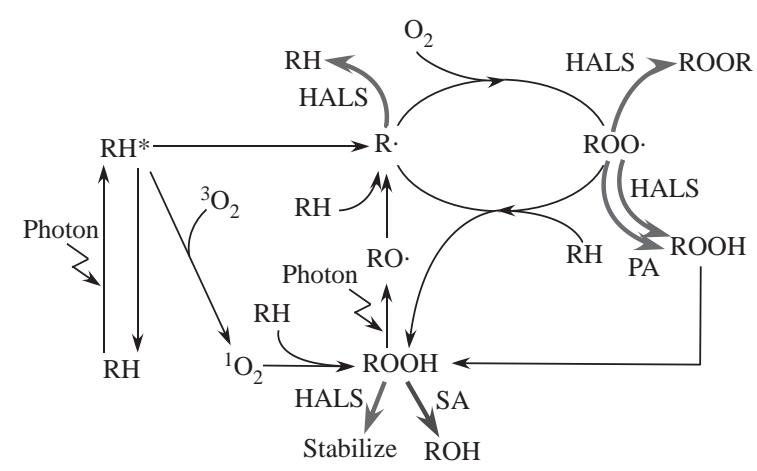

Fig. 4 Schemes of photo-stabilization by antioxidants and light stabilizer.

Table 1 Absorption and emission wavelengths of PSPs.

\begin{tabular}{cccc}
\hline Luminescent dyes & $\mathrm{Ru}\left(\mathrm{Ph}_{2} \text {-phen }\right)^{17)}$ & $\mathrm{H}_{2}$ TFPP & PBA $^{18)}$ \\
\hline$\lambda_{\mathrm{ab}}(\mathrm{nm})$ & 463 & 415 & 337 \\
$\lambda_{\mathrm{em}}(\mathrm{nm})$ & 618 & 645 & 480 \\
\hline
\end{tabular}

$\lambda_{\mathrm{ab}}$ : peak absorption wavelength, $\lambda_{\mathrm{em}}$ : peak emission wavelength

によって様々な種類に分類される. 安定化剂をPSP と共 に使用する場合, 酸素消光を利用した圧力計測に影響を与 えないことが要求される. 本研究では, 色素の光励起およ び酸素との消光反応を妨害するような作用をもたないフ エノール系酸化防止剤（Phenolic Antioxidant, PA)，イオ ウ系酸化防止剤（Sulfuric Antioxidant, SA)，ヒンダード アミン系光安定化剤 (Hindered Amine Light Stabilizer, HALS)の 3 種類を使用した. 以下では, これらの安定化 剂の作用を簡単に述べる(Fig. 4 参照)。

（1）フェノール系酸化防止剂

フェノール系酸化防止剂はラジカル捕捉剤の一種で, 自 動酸化プロセスにおいて発生するペルオキシラジカル (ROO・) と自身が反応することで反応性の低いヒドロペ ルオキシドを生成し, 自動酸化の進行を防ぐ機能をもつ.

（2）イオウ系酸化防止剂

イオウ系酸化防止剤はヒドロペルオキシド分解剤とし ての機能をもつ.この種の安定化剤は不安定なヒドロペル オキシドを分解して安定な化合物に変え, 自動酸化への進 展を防ぐ.

（3）ヒンダードアミン系光安定剤

ヒンダードアミン系光安定剤は自動酸化の進行の防止 と, ヒドロペルオキシドの安定化の 2 つの機能をもつ. ヒンダードアミン系光安定剤は酸素の存在下で光を吸収 すると, 自身が分解し, ニトロラジカルを生成する.この ラジカルが自動酸化を進行させる 2 種のラジカル $(\mathrm{R} ・$, $\mathrm{ROO}$ ・) に作用し, 反応性の低い化合物 $(\mathrm{RH}, \mathrm{ROOR})$ に 作り変える. 
Table 2 Properties of optical band-pass filters used.

\begin{tabular}{cccc}
\hline Luminescent dyes & $\mathrm{Ru}\left(\mathrm{Ph}_{2}\right.$-phen) & $\mathrm{H}_{2}$ TFPP & PBA \\
\hline Band-pass filter (A) & Sigma Koki, BLF-390B & Sigma Koki, BLF-390B & Sigma Koki, UTUAF-33U \\
Center Wavelength (nm) & 406 & 406 & 314 \\
Transmission at center wavelength (\%) & 78 & 78 & 85 \\
FWHM (nm) & 117 & 117 & 138 \\
\hline Band-pass filter (B) & Melles Griot, 03FIV046 & Melles Griot, 03FIV014 & Melles Griot, 03FIV006 \\
Center Wavelength (nm) & 600 & 664 & 513 \\
Transmission at center wavelength (\%) & 54 & 73 & 77 \\
FWHM (nm) & 46 & 81 & 86 \\
\hline
\end{tabular}

\section{5. 実験装置および方法}

本実験で使用する PSP は，バインダーに TLC シリカ ゲルプレート(MERCK 製 Silicagel 60)を, 発光色素に PBA (東京化成工業製), $\mathrm{Ru}\left(\mathrm{Ph}_{2}\right.$-phen) (GFS Chemicals 製), $\mathrm{H}_{2}$ TFPP (Porphyrin Product 製)を用いたものである (以降,これらの色素を含む PSP をそれぞれ PBA-PSP, $\mathrm{Ru}\left(\mathrm{Ph}_{2}\right.$-phen)-PSP, $\mathrm{H}_{2}$ TFPP-PSP と記す). 安定化剂と して, PA (Ciba Specialty Chemicals 製 IRGANOX1010), SA (ADEKA 製 AO-412s), HALS (Ciba Specialty Chemicals 製 TINUVIN292)を使用した. PSP は, 色素 を含む溶液に TLC プレートを 4 時間程度浸けることで作 製した. 安定化剂を添加寸る場合は, 色素と共に溶媒に溶 かし, TLC プレートに吸着させた. 色素の濃度, 安定化 剤の濃度は共に, 溶媒に対する重量比で $1000 \mathrm{ppm}$ とした。 なお, この濃度で安定化剂を添加しても, PSP の圧力感 度に大きな変化が生じないことを別途確認している。

Fig. 5 に実験装置の概略を示す. 水銀キセノンランプ （浜松ホトニクス製 L7212-01，200 W)を励起光源とし, 集光レンズ(浜松ホトニクス製 E5147)を取り付けた光フ アイババンドル(浜松ホトニクス製 A2873)を用いて圧力 容器内の PSP 上に励起光を照射した. 集光レンズから PSP までの距離は $170 \mathrm{~mm}$ で, 励起光のPSP 表面に対す る入射角は約 30 度であった. このとき PSP が発するルミ ネッセンスの強度を光電子増倍管(PMT(PhotoMultiplier Tube)，浜松ホトニクス製 R7236)によって計測した。な お, 励起光源の出力は, わずかではあるが時間的に変化す るため, ルミネッセンス強度測定と同時に APD (Avalanche PhotoDiode)モジュール (松定プレシジョン製 APM-IR516-LR）を用いて励起光強度を計測し， PMTの 出力を補正した. APD モジュールの出力およびアンプ (浜 松ホトニクス製 C1053-03）で増幅した PMT の出力は, ローパスフィルタ(エヌエフ回路設計ブロック製 3627 , カ ットオフ周波数 $50 \mathrm{~Hz}$ )を介してデジタルオシロスコープ (横河電機製 DL1540C)上で記録(サンプリングレート 10 $\mathrm{kS} / \mathrm{s})$ した.

光源から発せられる光から PSP の励起に必要な波長域

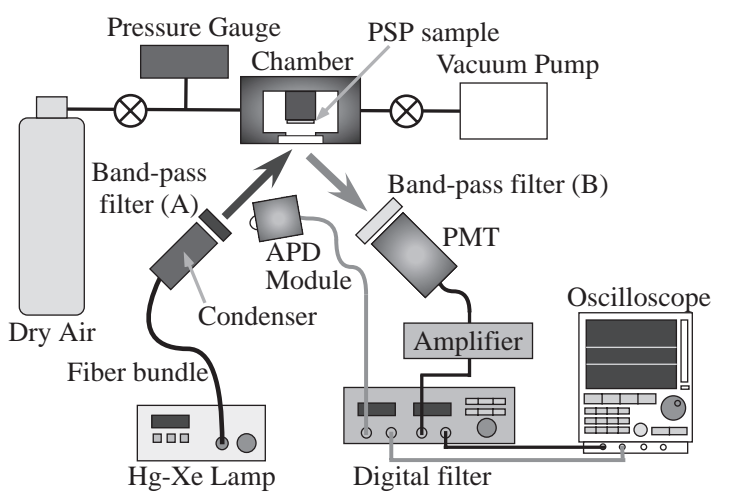

Fig. 5 Experimental apparatus for aging test.

の光のみを取り出すために光ファイババンドル先端の集 光レンズ前方に光学フィルタ(バンドパスフィルタ)を設置 した．また， PMT の前方に光学フィルタ(バンドパスフィ ルタ)を取り付けることで, 圧力容器や PSP に反射した励 起光を遮断し,ルミネッセンスの発光強度のみを選択的に 計測した. 発光色素はそれぞれ異なる励起波長, 発光波長 をもつため(Table 1 参照), Table 2 に示寸ようにPSP に 用いられる色素にあわせて光学フィルタを交換した.

圧力容器内には乾燥空気を充填し, 室温・大気圧下で励 起光強度と PSP が発するルミネッセンスの発光強度の時 間変化を計測した．計測は，励起光照射後 300 秒までは 30 秒ごとに, それ以降 1800 秒までは 60 秒ごとに行い, $300 \mathrm{~ms}$ 間の平均值を記録した。実験は, 安定化剂を添加 していないPSP と 3 種類の安定化剂を添加したPSPに対 して行った.

\section{6. 実験結果および考察}

\subsection{PBA-PSP}

Fig. 6 に安定化剤を添加していない PBA-PSP のルミ ネッセンス強度比の時間変化を示す. 横軸は励起光の照射 時間, 縦軸はルミネッセンス強度 $I$ を励起光照射直後のル ミネッセンス強度 $I_{T=0}$ で正規化した值を表している. 作成 した 1 枚の PSP プレート $(50 \mathrm{~mm} \times 50 \mathrm{~mm})$ を小片 $(15 \mathrm{~mm}$ $\times 15 \mathrm{~mm}$ )に切り分け, 3 つの小片に対して 1 回ずつ実験 を行なった. Fig. 6 には小片毎のルミネッセンス強度比 


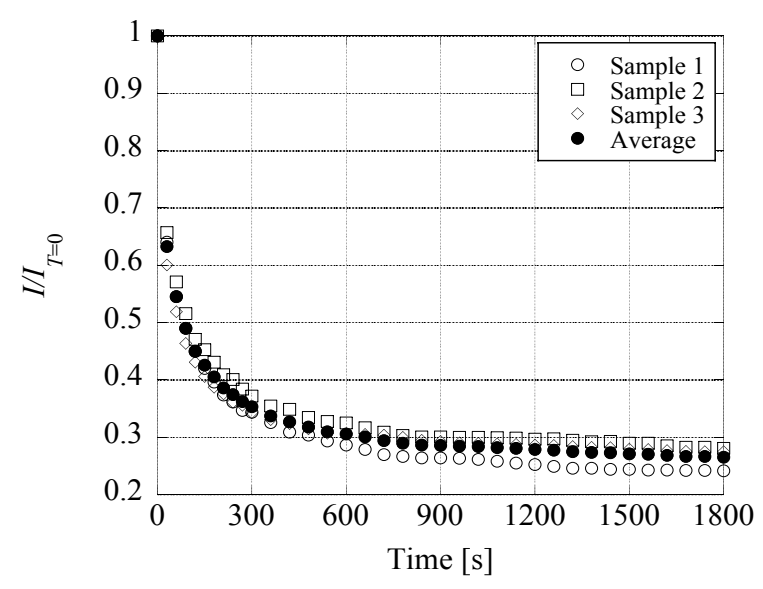

Fig. 6 Photodegradation of PBA-PSP without stabilizers.

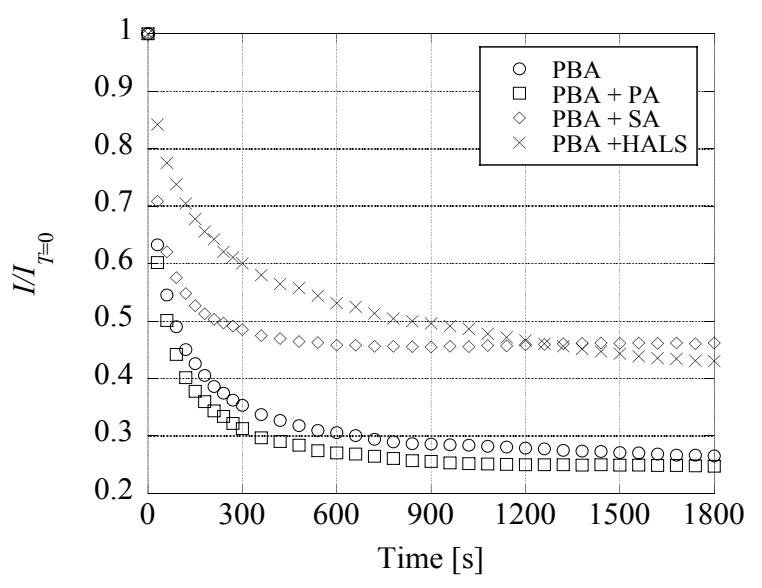

Fig. 7 Effects of stabilizers on the photodegradation of PBA-PSP.

(Sample 1ー3 と表す)とそれらの平均值の時間変化を表し ている. サンプル間のばらつきはこの図に示される程度で あり, 平均值からの隔たりは最大で $2.4 \times 10^{-2}$ であった.

以下では平均值を用いて安定化剤の効果について議論す る. Fig. 6 に示されるように, PBA-PSP は, 他の 2 つの 色素を用いた PSP (後述) と比較して光劣化の進行が速 く, 励起光照射後 300 秒におけるルミネッセンス強度比の 平均值は初期值の $35 \%$ となった.

安定化剂を添加した場合の実験結果をFig. 7 に示す. SA と HALS を添加した場合, 励起光照射後 300 秒間の強 度比の時間減少率が安定化剤を添加していない場合, すな わち, PBA 単体よりも小さくなっており, 光劣化の進行 が抑制されていることがわかる.これは陽極酸化アルミニ ウムをバインダーとして採用した場合の結果 11) とも定性 的に一致している. SA と HALS はともにヒドロペルオキ シドを安定化させる働きをもっているので, これらの添加 によって光劣化が抑制されたことは, PBA-PSP の光劣化 にヒドロペルオキシドが関与していることを示唆してい

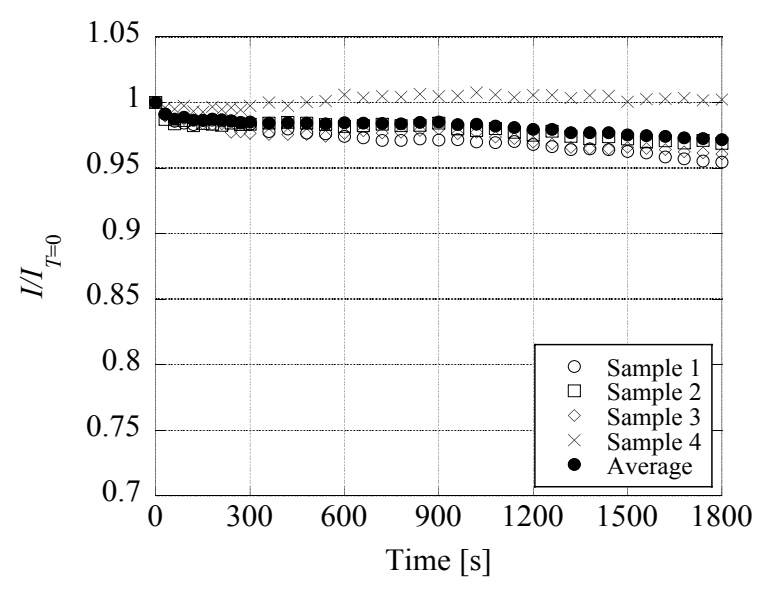

Fig. 8 Photodegradation of $\mathrm{Ru}\left(\mathrm{Ph}_{2}\right.$-phen)-PSP without stabilizers.

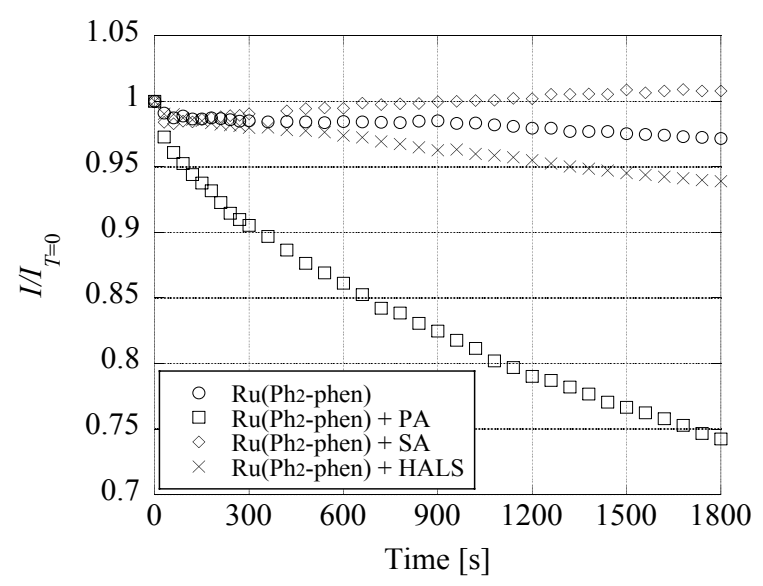

Fig. 9 Effects of stabilizers on the photodegradation of $\mathrm{Ru}\left(\mathrm{Ph}_{2}\right.$-phen)-PSP.

る.一方, PA を添加した場合, PBA 単体の場合に比べ強 度比の時間減少率が大きくなり, 劣化が進行している. PA は反応性の高いペルオキシラジカルを捕捉し，より反応性 の低いヒドロペルオキシドを生成することで, 自動酸化の 進行を抑制する働きをもっているが，上述したように PBA-PSP の光劣化がヒドロペルオキシドの影響を受けて いるものとすれば，PA の添加による光劣化の促進を説明 することができる.

\section{2 $\mathrm{Ru}\left(\mathrm{Ph}_{2}\right.$-phen)-PSP}

安定化剂を添加していない $\mathrm{Ru}\left(\mathrm{Ph}_{2}\right.$-phen)-PSP の結果 をFig. 8 に示す. $\mathrm{Ru}\left(\mathrm{Ph}_{2}\right.$-phen)-PSP では作成した 1 枚 の PSP プレートを小片に切り分け, 4 つの小片に対して 1 回ずつ実験を行なった. Fig. 8 には小片毎のルミネッセン ス強度比とそれらの平均值の時間変化を表している. サン プル間のばらつきは先に示したPBA-PSP と同程度であり, 平均值からの隔たりは最大で $3.1 \times 10^{-2}$ であった. Fig. 8 からわかるように, PBA-PSP と比べて， $\mathrm{Ru}\left(\mathrm{Ph}_{2}\right.$-phen)-PSP は光劣化の進行が非常に遅く, 励起光 


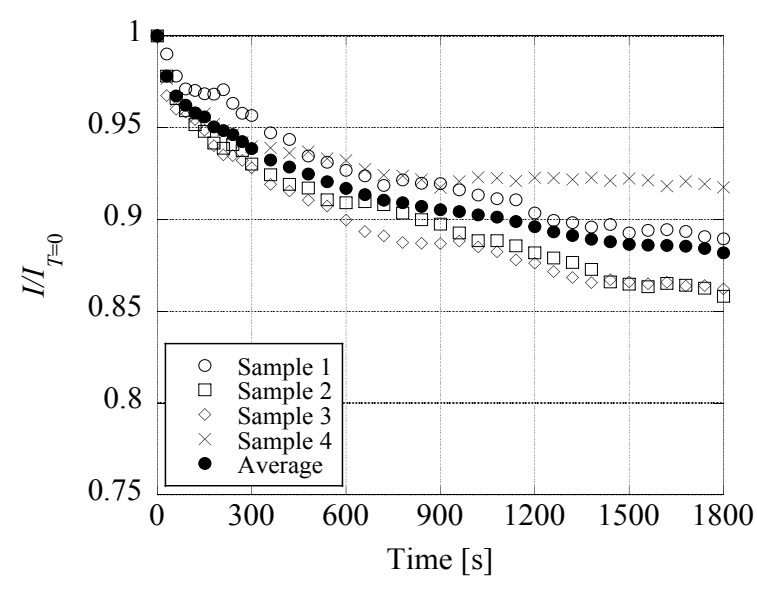

Fig. 10 Photodegradation of $\mathrm{H}_{2}$ TFPP-PSP without stabilizers.

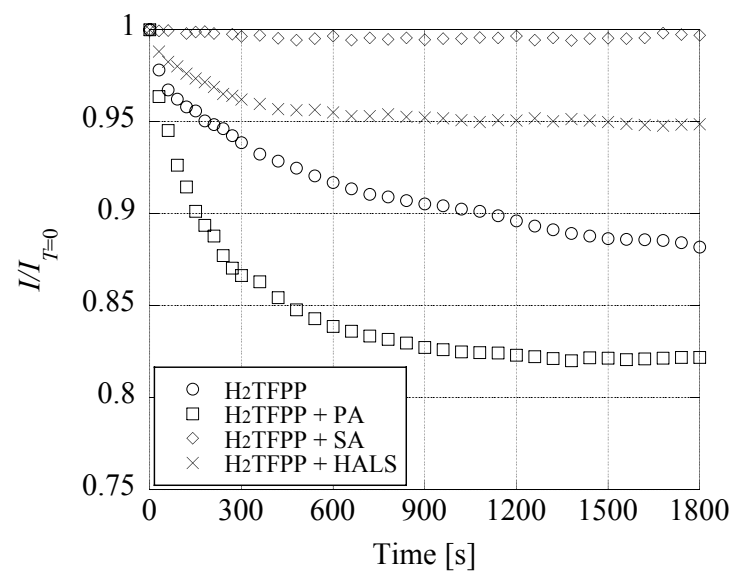

Fig. 11 Effects of stabilizers on the photodegradation of $\mathrm{H}_{2}$ TFPP-PSP.

を 1800 秒間照射した後においても，ルミネッセンス強度 比は初期值の $97 \%$ 程度であった。

Fig. 9 は安定化剂を添加した $\mathrm{Ru}\left(\mathrm{Ph}_{2}\right.$-phen)-PSP に対 する結果であり，4つの小片に対して行った実験結果の平 均值を示したものである.PA を添加した場合, PBA-PSP の場合と同様に光劣化の進行が速まることがわかる.ただ し, その程度は PBA-PSP の場合と比べて大きい. 一方, SA と HALS の添加による光劣化傾向の変化も励起光照射 後 300 秒以降にみられるが, サンプル間のばらつきと同程 度であった。

\section{3 $\mathrm{H}_{2}$ TFPP-PSP}

Fig. 10 に安定化剤を添加していない $\mathrm{H}_{2}$ TFPP-PSP の 実験結果を示す。この場合も作成した 1 枚の PSP プレー 卜を小片に切り分け，4つの小片に対して 1 回ずつ実験を 行なった. Fig. 10 には小片毎のルミネッセンス強度比と それらの平均值を表しており, 各小片の結果の平均值から の隔たりは最大で $3.5 \times 10^{-2}$ であった. $\mathrm{H}_{2}$ TFPP-PSP の場 合, ルミネッセンス強度の平均值は単調に減少し, 励起光
Table 3 Effects of stabilizers on the photodegradation of porous PSPs tested.

\begin{tabular}{lccc}
\hline & PA & SA & HALS \\
\hline $\operatorname{PBA}(T=300 \mathrm{~s})$ & 0.89 & 1.37 & 1.70 \\
$\operatorname{PBA}(T=1800 \mathrm{~s})$ & 0.93 & 1.74 & 1.62 \\
\hline $\operatorname{Ru}\left(\mathrm{Ph}_{2}\right.$-phen $)(T=300 \mathrm{~s})$ & 0.92 & 1.01 & 0.99 \\
$\operatorname{Ru}\left(\mathrm{Ph}_{2}\right.$-phen $)(T=1800 \mathrm{~s})$ & 0.76 & 1.04 & 0.97 \\
\hline $\mathrm{H}_{2} \mathrm{TFPP}(T=300 \mathrm{~s})$ & 0.92 & 1.06 & 1.03 \\
$\mathrm{H}_{2} \mathrm{TFPP}(T=1800 \mathrm{~s})$ & 0.93 & 1.13 & 1.08 \\
\hline
\end{tabular}

照射後 1800 秒で初期值の 88 \%に低下した.

Fig. 11 は安定化剂を添加した場合の結果と添加してい ない場合の結果を比較したものであり，4つの小片に対し て行った実験結果の平均值を示している。この図から，上 述した 2 つの色素の場合と同様に，PA を添加することで 光劣化が促進されていることがわかる.一方, SA や HALS を添加した場合には明らかに光劣化が抑制されており, 特 に SA の場合は 1800 秒間にルミネッセンス強度比の変化 は初期值の $1 \%$ 未満であった. HALS を添加した場合でも 励起光照射後 600 秒以降はルミネッセンス強度比がほぼ 一定となった。このように，PBA-PSP の場合と同様に， $\mathrm{H}_{2} \mathrm{TFPP}-\mathrm{PSP}$ においてもヒドロペルオキシドを安定化す る作用をもつ SA と HALS の効果が認められた。したが って, $\mathrm{H}_{2}$ TFPP-PSP の光劣化においてもヒドロペルオキ シド由来のラジカルが関与しているものと考えられる.

\section{4 安定化剂の効果:まとめ}

本実験で使用した 3 種の PSP に対する安定化剂の効果 をTable 3 にまとめた。ここでは, 安定化剤を添加してい ない場合のルミネッセンス強度比に対する比率でその効 果を表し, 励起光照射後 300 秒および 1800 秒の結果を示 す.

$\mathrm{PA}$ を添加した場合の結果は全て 1 より小さい值となっ ており，PAの添加によって光劣化が促進されたことがわ かる. 特に, $\mathrm{Ru}\left(\mathrm{Ph}_{2}\right.$-phen)の場合， 1800 秒時には単体の 場合に比べて $24 \%$ 減少しており，その影響は顕著であっ た。

一方, SA を添加した場合は全ての值が 1 を超えており， 光劣化の抑制効果が認められる.ただし， $\mathrm{Ru}\left(\mathrm{Ph}_{2}-\mathrm{phen}\right)$ の場合では, 安定化剤を添加していない場合に比べて最大 で $4 \%$ 程度であり,Fig. 8 に示したサンプル間のばらつき と同程度であった。

また，HALS の添加においても， $\mathrm{Ru}\left(\mathrm{Ph}_{2}\right.$-phen)の場合 にみられた変化はサンプル間のばらつきと同程度であっ たが，PBA や $\mathrm{H}_{2} \mathrm{TFPP}$ に対しては有意な差となって現れ ている.

\section{7. 結言}

本研究では, 代表的な発光色素と TLC プレートからな 
る 3 種類の多孔質型 PSP の光劣化特性を調べた. 有機高 分子材料に用いられている安定化剂をこれらのPSP に適 用し, その有効性を調べた. その結果得られた知見は以下 のようにまとめられる.

- PBA を発光色素とした PSP は他の 2 種類の色素を用 いた PSP に比べ光劣化の進行が速く, 励起光照射後 300 秒でルミネッセンス強度は初期值の $35 \%$ となっ た. 一方, $\mathrm{Ru}\left(\mathrm{Ph}_{2}\right.$-phen)を用いた PSP は光劣化の進 行が非常に遅く, 励起光を 1800 秒間照射した後にお いても,ルミネッセンス強度は初期值の $97 \%$ 程度であ った. また, $\mathrm{H}_{2} \mathrm{TFPP}$ を用いた PSP のルミネッセンス 強度は励起光照射後単調に減少し, 1800 秒で初期值の $88 \%$ 程度に低下した。

- $\mathrm{Ru}\left(\mathrm{Ph}_{2}\right.$-phen)を用いた PSP に対しては, イオウ系酸 化防止剤とヒンダードアミン系光安定剤の効果はサン プル間のばらつきと同程度であった。一方，フェノー ル系酸化防止剤は光劣化を促進する効果が現れた。

- $\mathrm{H}_{2} \mathrm{TFPP}$ を用いた PSP では, フェノール系酸化防止剂 を添加することで光劣化が促進された。一方，イオウ 系酸化防止剂やヒンダードアミン系光安定剤を添加し た場合には光劣化が抑制され，特に前者を添加した場 合は励起光照射後 1800 秒間に生じたルミネッセンス 強度の変化は初期值の $1 \%$ 未満であった。

\section{謝 辞}

東北大学 浅井圭介教授, 大分大学 天尾豊准教授には $\mathrm{H}_{2} \mathrm{TFPP}$ の吸収スペクトル, 発光スペクトルのデータを提 供していただきました。 また, Deutsches Zentrum für Luft- und Raumfahrt 江上泰広氏には有益な情報およ び御助言をいただきました。ここに記し, 深く感謝の意を 表します。

\section{参 考 文 献}

1) Liu, T. and Sullivan, J. P. : Pressure and temperature sensitive paints, Springer (2005).

2) Lakowicz, J. R. : Principles of fluorescence spectroscopy, 3rd ed., Springer (2006), p. 334.

3) Be11, J. H., Schairer, E. T., Hand, L. A., and Mehta, R. D. : Surface pressure measurements using luminescent coatings, Ann. Rev. Fluid Mech. (2001) pp. 155-206.

4) Mitsuo, K., Asai, K., Hayasaka, M., and Kameda, M. :
Temperature correction of PSP measurement using dual-1uminophor coating, J. Visualization, Vol. 6, No.3 (2003) pp. 213-223.

5) Goss, L., Jones, G., Crafton, J., Fonov S., and Fonov, V. : Temperature compensation for 1 ifetime-based pressure sensitive paint systems, ICIASF' 05 Record, Proc. 21st Int. Cong. on Instrum. in Aerospace Simulation Facilities (2005) pp. 282-291.

6) Yamashita, T., Sugiura, H., Nagai, H., Asai, K. and Ishida, K. : Pressure-sensitive paint measurement of the flow around a simplified car mode1, J. Visualization, Vol. 10, No. 3 (2007) pp. 289-298.

7) Gouterman, M. : Oxygen quenching of luminescence of pressure sensitive paint for wind tunnel research, J. Chem. Educ., Vol. 74, No. 6 (1997) pp. 697-702.

8) Moore, J, W. : 物理化学（下）第 4 版, 東京化学同人 (1974) pp. 799-800.

9) Baron, A. E., Danielson, J. D. S., Gouterman, M., Wan, J. R., Callis, J. B. and McLachlan, B. : Submillisecond response times of oxygen-quenched luminescent coatings, Rev. Sci. Instrum. Vo1. 64, No. 12 (1993) pp. 3394-3402.

10）大澤善次郎：高分子の光安定化技術, CMC (2000) pp. 108-126.

11) Egami, Y. and Asai, K. : Effects of antioxidants on photodegradation of porous pressure-sensitive paint, The 22nd AIAA Aerodynamics Measurement Technology and Ground Testing Conference, AIAA Paper 2002-2905 (2002).

12) Fujimatsu, N., Nakai, Y. and Fujii, K. : PSP measurement of the supersonic jet flows impinging on a flat plate at variable pressure ratios, Proc. 10th Int. Symp. on Flow Visualization (2002) (on CD-ROM).

13) Sakamura, Y., Kidoh, Y., Suzuki, T. and Matsumoto, M. : Time-resolved pressure measurements in shock-induced flows using a pressure-sensitive paint, Proc. 23rd Int. Symp. on Shock Waves (2002) pp. 456-62 (on CD-ROM).

14) Sakaue, H., Sakamura, Y., Kitamura, M., Ii jima, Y., Tabei, T. and Kameda, M. : Response time characterization of anodized aluminum pressure-sensitive paint, Proc. 11th Int. Symp. on Flow Visualization (2004) (on CD-ROM) .

15）丸山和博, 大槻哲夫 : 有機ラジカルおよび光反応, 丸善 (1983) pp. 117-119.

16）大澤善次郎：高分子の光安定化技術, CMC (2000) pp. 41-67.

17) Juris, A., Balzani, V., Barigelletti, F., Campagna, S., Belser, P. and Zelewsky, A, V.: Ru(II) polypyridine complexes: photophysics, photochemistry, electrochemistry, and chemiluminescence, Coordination Chem. Rev., Vol. 84, (1988) pp. 85-277.

18）浅井圭介: 感圧塗料による圧力分布の計測技術, 可視化情報, Vo1. 18, No. 69 (1998) pp. 97-103. 